\title{
THE INTERACTIONS OF CLIMATE AND BIOTIC FACTORS ON LIFE HISTORY CHARACTERISTICS AND VITAL RATES of Yellowstone CutThroat Trout in SPREAD CREEK, WY
}

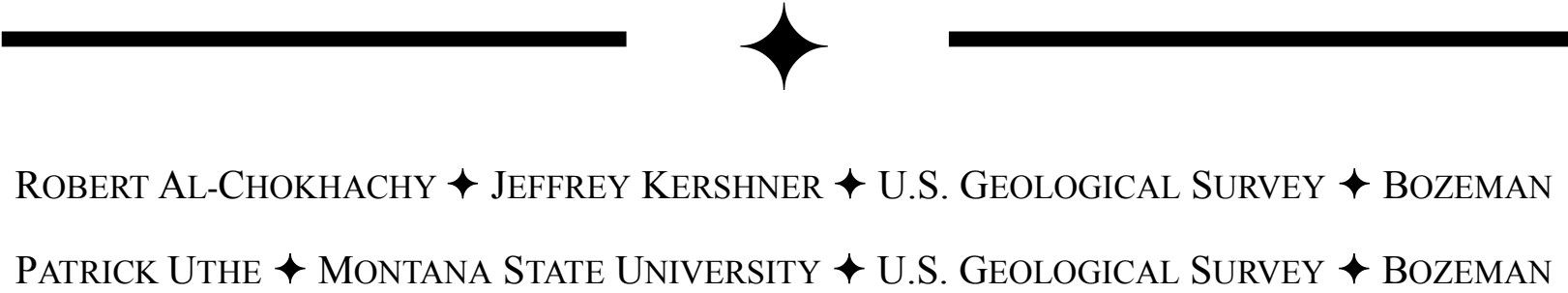

\section{$\uparrow \quad$ AbSTRACT}

Habitat degradation and introduction of nonnative salmonids have caused substantial declines in abundance and distribution of Yellowstone cutthroat trout. Additionally, global climate change is expected to exacerbate current threats through changes to thermal regimes, hydrology, stream productivity, and distributions of non-native species. Understanding how factors such as climate and local stressors (e.g., non-native species) interact to affect Yellowstone cutthroat trout is critical for developing management strategies to enhance future persistence. However, research investigating relationships among these factors and life history characteristics and vital rates of Yellowstone cutthroat trout is lacking. To address this need, we examined the influences of temperature, streamflow, food availability, and presence of brook trout on life history characteristics of Yellowstone cutthroat trout in Spread Creek, Wyoming. We used passive integrated transponder (PIT) tags and a combination of stationary and mobile PIT tag antennae within a capture-recapture framework to monitor growth, movement, and survival of Yellowstone cutthroat trout and brook trout throughout the Spread Creek drainage. Considerable differences existed in frequencies of movements between species and among tributaries. Significant differences existed among growth rates of trout in three tributary streams. Preliminary results suggest the observed differences were driven by the complex interactions of streamflows, fish densities, and prey abundances, rather than stream temperatures. We discuss our results in the context of maintaining diversity of life- history patterns within watersheds as a means to increase metapopulation resiliency. Our findings provide critical information needed to refine climate risk assessments and to better direct limited resources to ensure the long term persistence of the subspecies.

\section{$\downarrow \quad$ INTRODUCTION}

Yellowstone cutthroat trout is an integral part of natural ecosystems across the native range as a key resource for terrestrial and avian species and a recreational resource with strong socioeconomic values (Gresswell and Liss 1995; Wengeler et al. 2010). Relative to the historic distribution and abundance, Yellowstone cutthroat trout has experienced considerable declines as a result of habitat fragmentation and degradation and the introduction of non-native species (Gresswell 2011). Ultimately, understanding how anthropogenic-related disturbances influence Yellowstone cutthroat trout is an important step in prioritizing future restoration and directing management and conservation efforts.

In addition to current limiting factors, Yellowstone cutthroat trout is likely to be significantly influenced by global climate change, particularly given the narrow thermal tolerances of this species (Williams et al. 2009). However, the large elevational and latitudinal gradients suggest the effects of global climate change are likely to vary considerably across basins. Major basins across the intermountain West have experienced a consistent decrease in summer discharge and increase in stream temperatures over the past 50 years (Isaak et al. 2012). The concurrent 
effects on biotic factors such as non-native species distributions (Wenger et al. 2011a; 2011b) and macroinvertebrate prey (Harper and Peckarsky 2006) will also play a major role in shaping future cutthroat trout distributions.

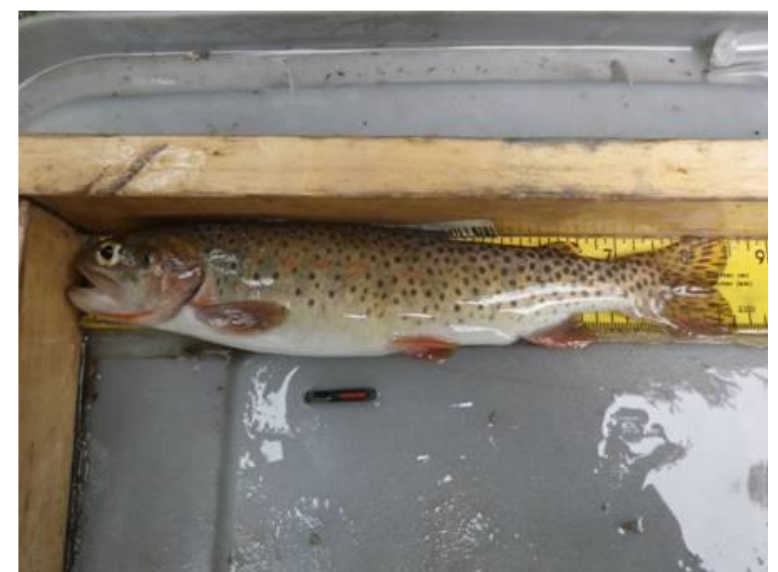

Figure 1. A picture of a resident Yellowstone cutthroat trout in Spread Creek. Note the PIT-tag used for addressing research questions.

While there has been work describing how climate change may influence spatial patterns of salmonids (e.g., Wenger et al. 2011a, 2011b), there continues to be a paucity of information linking salmonid life-history patterns and demographic rates to climate. To address the conservation and management needs of Yellowstone cutthroat trout (Figure 1), we conducted research to increase our understanding of the life-history patterns and the potential effects of habitat fragmentation and climate change on this native salmonid. Our specific objectives were to: 1) Monitor the Yellowstone cutthroat trout population connectivity and spawning locations of migratory Yellowstone cutthroat trout after the removal of an existing migration barrier, 2) Identify how stream temperature, stream flows, and food availability influence life-history characteristics of Yellowstone cutthroat trout, and 3) Quantify Yellowstone cutthroat trout demographic and vital rates across different portions of the stream network in the Spread Creek drainage, and how these factors differ with and without non-native brook trout Salvelinus fontinalis.

\section{STUDY AREA}

The study area for this research includes portions of the stream network within the Spread Creek drainage in northwestern Wyoming (Figure 2). Spread Creek is a relatively large drainage with over $200 \mathrm{~km}$ of fish-bearing streams. Prior to 2010, an impassible barrier in the form of a diversion dam existed approximately $7.2 \mathrm{~km}$ upstream from the confluence with the Snake River. In the fall of 2010, collaborative efforts by state and federal agencies and Trout Unlimited helped remove this barrier and reconnect the Spread Creek drainage with the Upper Snake River.

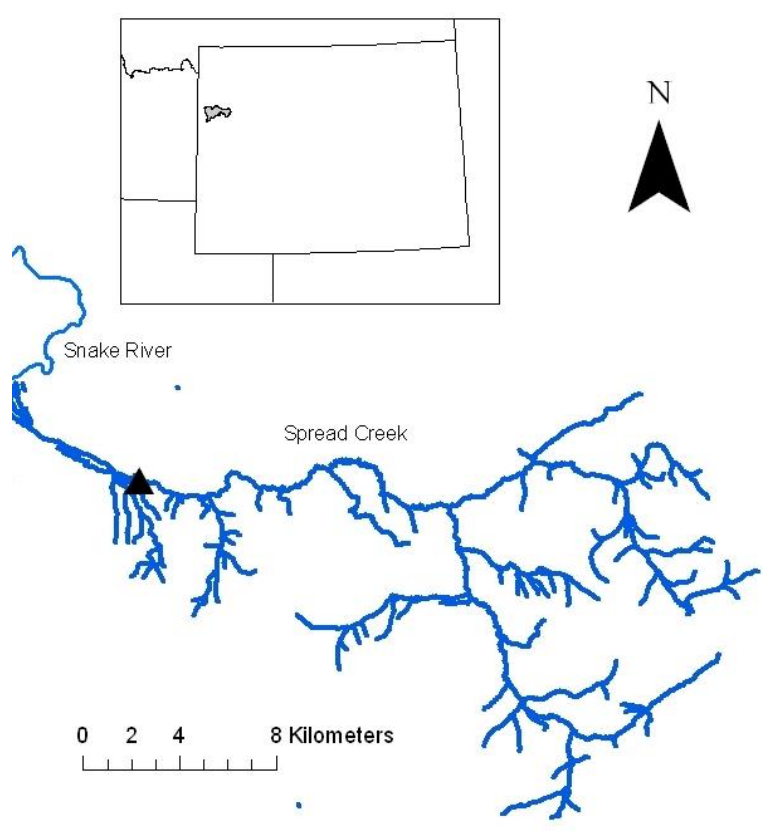

Figure 2. The location of the Spread Creek drainage in Wyoming and the stream network and former diversion dam (black triangle) location in the drainage.

Spread Creek hosts a variety of native fishes in addition to Yellowstone cutthroat trout, including bluehead sucker (Catastomus discobolus), Utah sucker (C. ardens), longnose dace (Rhinichthys cataractae), mottled sculpin (Cottus bairdii), and Paiute sculpin (C. beldingi). Non-native brook trout also exist in the Spread Creek drainage.

\section{MeTHODS}

\section{Fish sampling}

Our study area included portions of Spread Creek, South Fork Spread Creek, Grouse Creek, Leidy Creek, and Rock Creek. Additional reaches were added to the 2011 sampling framework to increase sampling coverage. The additional reaches were chosen based on gaps in stream length not covered by the 2011 framework and were identified using ArcGIS. Once the reach was located, we began sampling at the nearest pool tail; the length of each reach varied by size of stream: Spread Creek $=200 \mathrm{~m}$; SF Spread 
Creek $=200 \mathrm{~m}$; and $100 \mathrm{~m}$ for Grouse, Leidy, and Rock Creeks.

Fish sampling consisted of a summer and fall component in the tributaries and a single summer event in South Fork Spread Creek and mainstem Spread Creek. Summer sampling in the tributaries began the first week of July and was completed the third week of July. Fall sampling was conducted between September 22 and October 5. South Fork Spread Creek and Spread Creek were sampled between July 20 and August 3. Fish were captured exclusively with backpack electrofishing units in the tributaries and a combination of electrofishing and angling in Spread Creek and South Fork Spread Creek. We conducted one-pass surveys in the majority of the sample sites. However, to estimate capture efficiency, we block netted (20-mm mesh) and conducted 3-pass electrofishing surveys in 3 reaches in each tributary. No three pass surveys were conducted in Spread Creek or South Fork Spread Creek this year.

Once captured, individuals were placed in a stream-side holding container and identified to species. For all non-salmonids and salmonids $<80$ $\mathrm{mm}$, we recorded lengths and weights and immediately returned individuals to the stream. For abundant species (i.e., sculpin), we only recorded length and weight information for the first 15 individuals per reach, then enumerated individuals. We anesthetized all salmonids $>80 \mathrm{~mm}$ with a diluted solution of clove oil, recorded length and weight measurements, and inserted passive integrated transponder tags (PIT-tags; half duplex, Oregon RFID) ventrally and anterior to the pectoral fins. For all salmonids between 80 and $120 \mathrm{~mm}$ we inserted $12 \mathrm{~mm}$ PIT-tags and fish $>120 \mathrm{~mm}$ we used $23 \mathrm{~mm}$ PIT-tags. We inserted PIT-tags into a small insertion (2-4 mm) made with a scalpel. After tagging, we placed all fish in a flow-through recovery tank placed in the stream channel. Once fish regained equilibrium, we used hand nets to return fish to slow-water sections within the sampled reach. Animal capture protocols have been approved by Montana State University's Institutional Animal Care and Use Committee (IACUC).

\section{Salmonid biomass}

We estimated average reach widths using three width measurements equally spaced throughout each reach. Average depths from the July flow measurement were then used with the average widths to estimate the volume per reach. We estimated average salmonid biomass for Grouse, Leidy, and Rock Creeks. We adjusted the total biomass caught in each reach based on the average capture efficiency per stream that was estimated from the three pass electrofishing events (see results section), and adjusted biomass estimates from each site for the entire stream and divided by the average volume per $100 \mathrm{~m}$ reach in each stream.

\section{Summer growth}

Growth was estimated for all individuals recaptured during the fall sampling event. Daily growth rate was standardized for mass using the equation

$G_{s}=\left(W_{t}^{b}+W_{0}^{b}\right) *(b t)^{-1}$

where $G_{s}$ is mass-standardized growth rate, $W_{t}$ is mass at recapture, $W_{0}$ is mass at initial capture, $t$ is time between capture and recapture, and $b$ is the allometric growth constant $(\mathrm{YCT}=0.472, \mathrm{BKT}=0.485)$. The allometric growth constant was estimated from the slope of the regression of natural $\log$ of specific growth and natural log of mass as described by Ostrovsky (1995). The mass value used in the regression was estimated using the iterative process suggested by Elliott and Hurley (1995).

\section{Movement and capture-recapture}

Prior to fish sampling, we installed passive instream antennae adjacent to the formal diversion structure on Spread Creek and at the mouths of Grouse, Leidy, and Rock Creeks (Figure 3). Each antennae array, including the one positioned in the irrigation canal, consisted of two channel-wide loops. Having multiple loops in each channel allows for quantifying directionality of fish movement. A halfduplex reader (Oregon RFID multiplexor) was used to record movements at each antenna. The system at the old diversion site was powered by two solar panels, which together with the reader and rechargeable batteries were located between the current diversion structure and the Spread Creek Channel. Antennae located in the tributaries were powered by a single solar panel each.

After completion of fish sampling, we used mobile PIT-tag antennae to provide recapture information and information regarding movement for all PIT-tagged individuals. We used continuous surveys in each of the three tributaries and conducted a single continuous survey from the mouth of Leidy Creek on South Fork Spread Creek downstream to the old diversion site on Spread Creek. We conducted the mobile surveys using $2-3$ portable antennae, which included hoop antennae ( $\sim 0.3 \mathrm{~m}$ diameter) attached to 
a pole and mobile rectangular PVC frames $(1 \mathrm{~m} \times 3$ $\mathrm{m})$. During the mobile surveys, we covered the entire stream channel in a manner analogous to backpack electrofishing. Movement distances were calculated in ArcMap10.1 with the Origin-Destination Cost Matrix function. Movement estimates represent the distance from the midpoint of the sampling reach where the fish was tagged to the point where it was detected. The estimates have a maximum resolution of $50 \mathrm{~m}$ so any movement estimate less than that is considered withinreach movement.

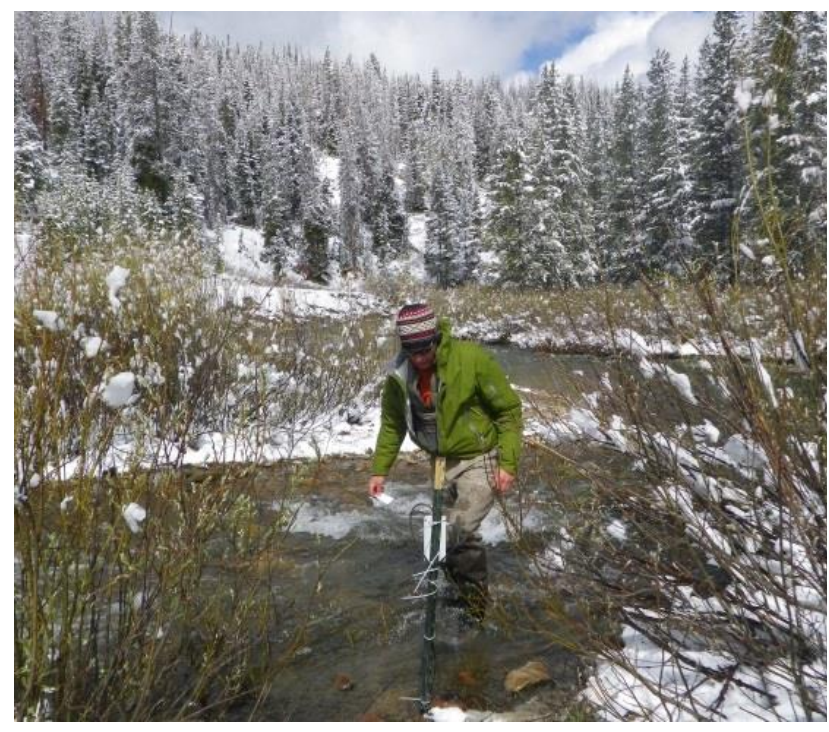

Figure 3. Montana State University graduate student Patrick Uthe installing a PIT-tag antenna on Leidy Creek.

\section{Entrainment within the diversion structure}

In addition to observations from PIT-tag antennae within the diversion structure, opportunistic field sampling in October 2012 occurred in response to the observation of entrained fish within the diversion ditches. In response, biologists from Wyoming Game and Fish (WGF), Grand Teton National Park, and the USGS sampled the diversion structure and below the diversion in the proximate diversion ditches using backpack electrofishing on September $26-27$, October $4^{\text {th }}$, and October $18^{\text {th }}$. In addition, biologists from Wyoming Game and Fish sampled the Elk Ranch Reservoir using a floating gill net $(0-2 \mathrm{~m})$, which was set for nearly four hours. All fish captured were measured for length, checked for PIT-tags and returned to Spread Creek below the diversion structure.

\section{Temperature and streamflow}

We deployed continuous stream temperature loggers at numerous locations in the study area. Temperature loggers consisted of a combination of Onset Pendants and Onset V2 temperature loggers. (Dunham et al. 2005) In addition to temperature loggers, we deployed pressure-transducers to continuously measure stream flow height (i.e., stage) and develop stage-discharge relationships. We installed the pressure transducers in Rock Creek, Leidy Creek, Grouse Creek, South Fork Spread Creek and North Fork Spread Creek above the confluence, and at the site of the historic diversion structure on Spread Creek. Pressure transducers in tributaries were deployed at a site near the mouths and at a site above the top site on each stream. A temperature logger was deployed at the midpoint of each of the three tributaries. Pressure transducers were placed in a perforated $5 \mathrm{~cm}$ PVC pipe, partially buried in the substrate and attached to rebar. To establish stagedischarge relationships, we measured discharge at each location during the summer and fall. To avoid losing pressure transducers due to ice, we removed the pressure transducers in early November, and will replace these prior to the spring runoff.

\section{Food availability}

We measured food availability bi-weekly from July-September at a fixed sampling site (located between the mouth and the lowest site in Grouse, Leidy, and Rock Creeks. Each sampling event consisted of a morning sample starting at one hour after sunrise and an evening sample starting at one hour prior to sunset. This regiment was chosen to capture the beginning of the crepuscular increase in drift density that is an important feeding period for salmonids.

Two drift nets $(25 \times 45 \mathrm{~cm}, 500 \mu \mathrm{m})$ were deployed adjacently in the thalweg of a fast-water channel unit. Nets remained in the channel for one hour to maximize the volume of water sampled without risking backflow due to clogging. Nets were deployed at least $2 \mathrm{~cm}$ off the substrate to prevent benthic macroinvertebrates from crawling into the nets. Nets were always deployed so that the tops were above the water surface to capture drifting terrestrial invertebrates. Flow and water depth were measured directly after setting the nets and prior to retrieving them. This was used to calculate the volume of water sampled over the hour. The contents of the nets were transferred to storage jars and preserved with 95\% ethanol. Samples will be identified to the lowest possible taxa and converted to energy content estimates using dry-mass to energy equivalents from published literature. 


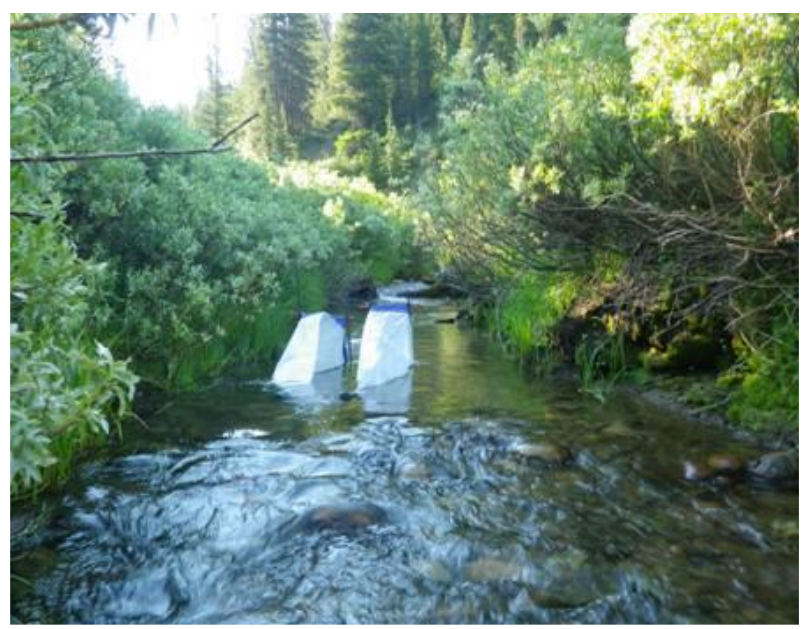

Figure 4. Drift nets used to quantify stream productivity through macroinvertebrate drift.

\section{$\downarrow \quad$ PRELIMINARY RESUlTS}

\section{Fish sampling}

We sampled 67 reaches 69 eticula $8,754 \mathrm{~km}$ during the 2012 summer field season. During the fall, the 49 tributary reaches were resampled. During the summer sampling a total of 61 brook trout and 368 Yellowstone cutthroat trout were captured. Two brook trout and 16 Yellowstone cutthroat trout were recaptured individuals. We implanted 55 brook trout and 320 cutthroat trout with PIT tags. During the fall sampling season we captured 90 brook trout and 484 cutthroat trout. Of these, 19 brook trout and 53 Yellowstone cutthroat trout were recaptured individuals. We implanted 67 brook trout and 324 Yellowstone cutthroat trout with PIT tags. The first documented presence of brook trout in Leidy Creek occurred when we captured a single individual $(101 \mathrm{~mm})$ during fall sampling. Size distributions varied among the tributaries during both sampling seasons. Some reaches in Grouse Creek exhibited a considerable shift in species composition between the summer and fall sampling events (Figure 5). In addition to salmonids, we captured a total of 2 longnose dace, 459 cottids, and 2 catostomids. The estimated capture efficiency was $0.69(95 \% \mathrm{CI} \pm 0.23)$ in Grouse Creek, 0.53 (95\% CI \pm 0.24$)$ in Leidy Creek, and $0.70(95 \% \mathrm{CI} \pm 0.06)$ in Rock Creek.

\section{Salmonid biomass}

Biomass varied considerably across streams. We estimated average biomass as $16.4 \mathrm{~g} / \mathrm{m}^{3}$ in Grouse Creek, $12.3 \mathrm{~g} / \mathrm{m}^{3}$ in Rock Creek, and $6.0 \mathrm{~g} / \mathrm{m}^{3}$ in Leidy Creek.

\section{Summer growth}

We estimated growth over the summer growing season for 11 trout in Leidy Creek, 18 trout in Rock Creek, and 33 trout (19 brook, 14 Yellowstone cutthroat trout) in Grouse Creek. Average massstandardized growth rates varied among the three streams (Figure 5). Growth rates were not significantly different between species in Grouse Creek. Trout in Rock Creek had significantly lower growth rates than trout in Grouse and Leidy Creeks (Figure 6).

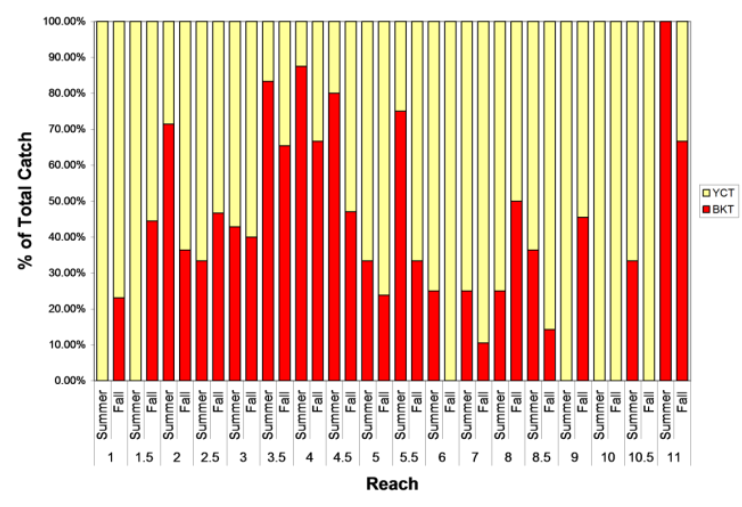

Figure 5. Seasonal changes in species composition of Yellowstone cutthroat trout (yellow) and brook trout (red) from electrofishing surveys in sample reaches in Grouse Creek during 2012. Reach numbers (i.e., 1-10) correspond to locations within Grouse Creek with the lowest number near the mouth of Grouse Creek and the highest reach corresponding to the uppermost sample reach.

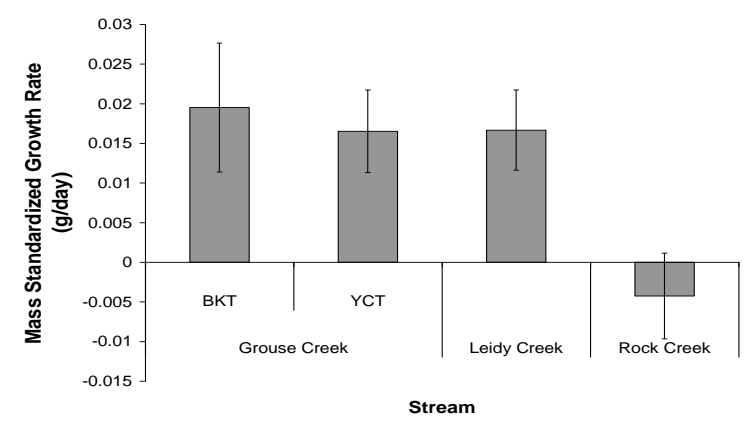

Figure 6. Average relative growth rates among Grouse, Leidy, and Rock Creeks. Growth rates calculated as relative growth in mass over the period between summer and fall sampling occasions. Estimates shown with $95 \%$ confidence intervals.

\section{Movement and capture-recapture}


The antennae on Spread Creek were installed on April 26, but were dislodged during runoff and reinstalled on June 20. They remained operational until they were removed on November $2^{\text {nd }}$. The antennae in the diversion ditch operated from April 26 to the end of August, when it was removed during maintenance on the irrigation canal. The antennae detected a total of 11 trout throughout the operational period. Three of the fish were detected passing into the irrigation canal during the summer. One moved back out of the canal and proceeded downstream past the antennae in the main channel. The tagging locations of fish moving past the antennae were distributed throughout the Spread Creek basin. All the fish were Yellowstone cutthroat trout and ranged in size from 139-362mm.

The antennae on the tributaries were installed after peak runoff and remained operational throughout the summer and most of the fall (Grouse Creek, May 25 - November 6; Leidy Creek, May 24 - November 6; Rock Creek June 7- October 29). The number of fish passing over the antennae varied substantially across streams. Grouse Creek was the only stream that had an increase in downstream movement during the late fall.

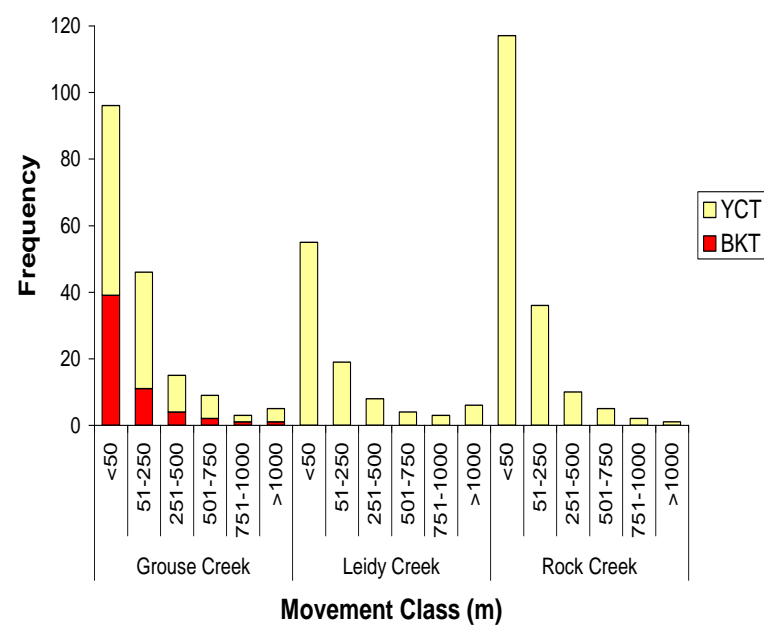

Figure 7. Frequency histograms of movement distances from three mobile PIT-tag surveys in Grouse Creek, Leidy Creek, and Rock Creek in 2012. Movements less than 50m are considered within-reach movement.

We surveyed a total of $38 \mathrm{~km}$ with mobile PIT-tag readers. Mobile tracking on South Fork Spread Creek and Spread Creek consisted of one event conducted during the middle of August. The mobile surveys on the tributaries were conducted at the end of June, July, and beginning of November. Overall, we detected 385 different trout for a total of 478 detections over the course of all mobile tracking events. Frequencies of movements varied across species and streams (Figure 7). Yellowstone cutthroat trout in Grouse creek exhibited the highest displacement rates with approximately $49 \%$ of total detections from fish remaining in the reach they were tagged in. Within reach detections accounted for 58\% of total detections in Leidy Creek and $68 \%$ of total detections in Rock Creek.

\section{Entrainment within the diversion structure}

From the 4 days of sampling the diversion structures, 310 Yellowstone cutthroat (median length $=200 \mathrm{~mm}$; range $=48-390 \mathrm{~mm}$ ) were captured and transported to lower Spread Creek (Figure 8). In addition to cutthroat trout we captured one mountain whitefish, two longnose dace, and 25 Paiute sculpin. No fish were captured in Elk Ranch Reservoir from the one gillnet survey; however, capture probabilities during daylight hours for visual predators is likely low and further work is needed to identify fish within the reservoir.

\section{Temperature and streamflow}

Stream temperatures and stream discharge were considerably different between 2011 and 2012 . Average August stream discharge in Spread Creek (above the diversion structure) during $2011\left(2.61 \mathrm{~m}^{3} / \mathrm{s}\right)$ was $55 \%$ higher than observed in $2012\left(1.68 \mathrm{~m}^{3} / \mathrm{s}\right)$; during September this pattern was exacerbated with 2011 discharge $\left(1.69 \mathrm{~m}^{3} / \mathrm{s}\right)$ nearly $70 \%$ higher than observed in $2012\left(1.07 \mathrm{~m}^{3} / \mathrm{s}\right.$; Table 1). Average stream temperatures in Spread Creek in August in 2011 were $11.6{ }^{\circ} \mathrm{C}$ and were over 2 degrees higher in 2012 $\left(13.7^{\circ} \mathrm{C}\right)$.

Table 1. The average (Standard deviation) discharge $\left(\mathrm{m}^{3} / \mathrm{s}\right)$ for Spread Creek above the diversion structure for August and September in 2011 and 2012.

\begin{tabular}{lll} 
& August & September \\
\hline 2011 & $2.61(0.86)$ & $1.69(0.34)$ \\
2012 & $1.68(0.41)$ & $1.07(0.19)$ \\
\hline
\end{tabular}

Across the three tributaries, we observed considerable differences in discharge but relatively similar temperatures during the summer months. Stream discharge was considerably higher in Grouse Creek and Leidy Creek than in Rock. Average summer discharge (July through September) was highest in Leidy Creek $\left(0.44 \mathrm{~m}^{3} / \mathrm{s} ; \mathrm{SD}=0.52\right)$, intermediate in Grouse Creek $\left(0.31 \mathrm{~m}^{3} / \mathrm{s} ; \mathrm{SD}=1.32\right)$, and lowest in Rock Creek $\left(0.07 \mathrm{~m}^{3} / \mathrm{s} ; \mathrm{SD}=0.11\right)$. Stream temperatures were relatively similar across the three tributaries, but we observed substantial differences in 
the lapse rates (i.e., how temperatures change within changing elevations: Table 2). Upper Grouse creek demonstrated the lowest stream temperatures across all sites

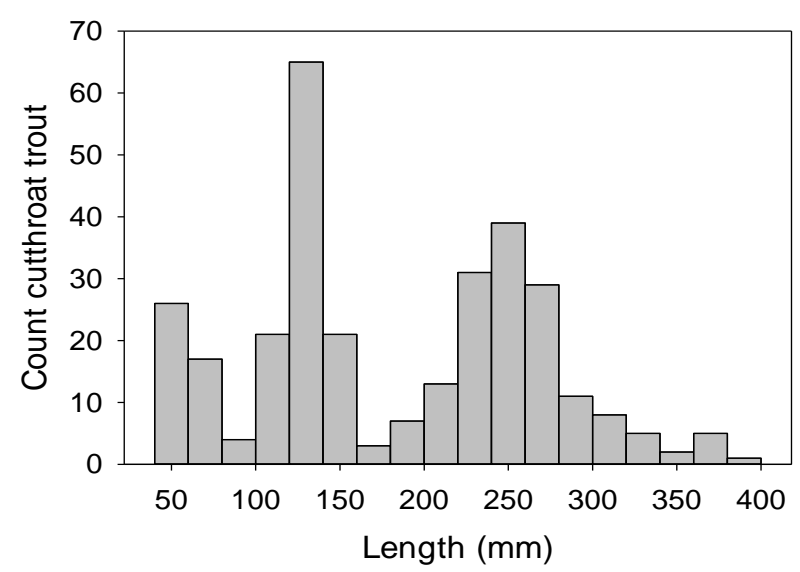

Figure 8. A histogram of the count and length of Yellowstone cutthroat trout entrained and captured in the diversion sediment trap and diversion ditches during four sampling occasions (four days) in late September and early October 2012.

Table 2. The maximum average weekly temperature (MWAT), maximum weekly average maximum temperature (MWMT), and the overall instantaneous maximum temperature (MDMT; as per Dunham et al. 2005) (Celsius) for locations within Spread Creek.

\begin{tabular}{lccc} 
& MWAT & MWMT & MDMT \\
\hline $\begin{array}{l}\text { Lower Grouse } \\
\text { Creek }\end{array}$ & 13.2 & 18.3 & 19.4 \\
$\begin{array}{l}\text { Upper Grouse } \\
\text { Creek }\end{array}$ & 7.4 & 10.8 & 11.2 \\
Lower Leidy Creek & 11.5 & 16.7 & 17.7 \\
Upper Leidy Creek & 15.5 & 16.9 & 17.9 \\
Lower Rock Creek & 12.9 & 16.2 & 17 \\
Upper Rock Creek & 12.5 & 15.0 & 18.4 \\
SF Spread Creek & 12.9 & 16.8 & 17.9 \\
NF Spread Creek & 11.6 & 16.7 & 18.3 \\
Spread Creek & 15.1 & 18.7 & 20.4 \\
\hline
\end{tabular}

\section{Food availability}

We collected six morning and evening samples between July and September in Rock, Leidy, and Grouse creeks. Two sampling occasions occurred in July, three occurred in August, and one occurred at the end of September. Samples have not yet been processed.

\section{MANAGEMENT IMPLICATIONS}

The life-history patterns of Yellowstone cutthroat trout in headwater tributaries appear to be complex. Both resident and migratory life-history forms are apparent in the Spread Creek drainage. Although preliminary, we found Yellowstone cutthroat trout growth to vary substantially across tributaries, suggesting the need to include measures of fish density and movement with growth to gain a better understanding of how climate-driven attributes (e.g., streamflow) can influence fish behavioral characteristics.

While the removal of the historic Spread Creek dam eliminated upstream barriers, our results suggest considerable entrainment still exists. Our results also suggest the need for additional sampling to better understand the extent of entrainment across a year. Our preliminary results indicate a diversion screen may be warranted in the future.

\section{ACKNOWLEDGEMENTS}

In addition to support from the UW-NPS Research Station, this project has received key funding from the U.S. Geological Survey and donations from the Jackson Hole Trout Unlimited Chapter. We would especially like to thank the Jackson Hole Chapter of Trout Unlimited, numerous volunteers from the Jackson Hole Chapter of Trout Unlimited, Rob Gipson, Brian Hines, and Tracy Stephens (Wyoming Game and Fish), US Forest Service, Chad Whaley and Sue Consolo Murphy (National Park Service), and the US Fish and Wildlife Service. We also would like to extend thanks to field technicians Nate Marotz and Chad Gabreski for help with data collection, and Hank Harlow, the staff at the UW research station, and Celeste Havener for their support.

\section{Literature CiTED}

Dunham JB, G Chandler, B Rieman, D Martin. 2005. Measuring stream temperature with digital data loggers: a user's guide. Gen. Tech. Rep. RMRSGTR-150WWW. Fort Collins, CO: U.S. Department of Agriculture, Forest Service, Rocky Mountain Research Station. $15 \mathrm{p}$.

Elliott JM, MA Hurley. 1995. The functional relationship between body size and growth rate in fish. Functional Ecology 9, 625-627. 
Gresswell RE. 2011. Biology, status, and management of the Yellowstone cutthroat trout. North American Journal of Fisheries Management 31:782-812.

Gresswell RE, WJ Liss. 1995. Values associated with management of Yellowstone cutthroat trout in Yellowstone National Park. Conservation Biology 9:159-165.

Harper MP, BL Peckarsky. 2006. Emergence cues of a mayfly in a high-altitude stream ecosystem: potential response to climate change. Ecological Applications 16:612-621.

Isaak DJ, Muhnfeld CC, Todd AS, Al-Chokachy R, Roberts R, Kershner JL, Fausch KD, Hostetler SW. 2012. The past as prelude to the future for understanding $21^{\text {st }}$ Century climate effects on Rocky Mountain trout. Fisheries 37:542-556.
Ostrovsky I. 1995. The parabolic pattern of animal growth: determination of equation patterns and their temperature dependencies Freshwater Biology 33: 357-371

Wengeler WR, DA Kelt, ML Johnson. 2010. Ecological consequences of invasive lake trout on river otters in Yellowstone National Park. Biological Conservation 143:11441153.

Wenger SJ, Isaak DJ, Dunham JB, Fausch KD, Luce, $\mathrm{CH}$, Neville HM, Rieman BE, Young MK, Nagel DE, Horan DL, Chandler GL. . 2011a. Role of climate and invasive species in structuring trout distributions in the interior Columbia River Basin, USA. Canadian Journal of Fisheries and Aquatic Sciences 68:988-1008.

Wenger SJ, Isaak DJ, Luce CH, Neville HM, Fausch KD, Dunham JB, Dauham JB, Dauwalter DC, Young MK, Elsner MM, Rieman BE, Hamlet AF, Williams JE. 2011b. Flow regime, temperature, and biotic interactions drive differential declines of trout species under climate change. Proceedings of the National Academy of Sciences 108:1417514180.

Williams JE, AL Haak, HM Neville, WT Colyer. 2009. Potential Consequences of Climate Change to Persistence of Cutthroat Trout Populations. North American Journal of Fisheries Management 29:533-548. 